\title{
Preliminary Bedrock Map of the Stratton \\ Mountain Quadrangle, Vermont
}

\section{by}

Nicholas M. Ratcliffe and William C. Burton

\author{
U.S. Geological Survey
}

Open File Report No. 89-200

This report is preliminary and has not be reviewed for conformity with U.S. Geological Survey editorial standards and stratigraphic nomenclature. 
LORRELATION OF MAP UNITS

Lover and

BASEMENT

Lover and BASEMENT of the

ABOUE THE

Lover and basement

ABOVE THE

GREEN MOUNTAINS MASSIF

WILMINGTON

SEARSBURG

FAULT

GAULT SYSTEM

SYSTEM

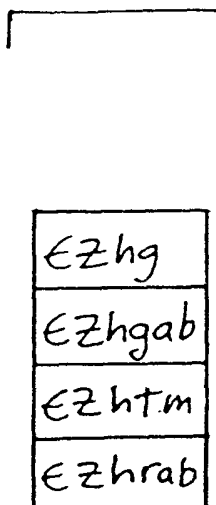

UPPER

PROTEROZOICLOWER CAMBRIAN

IGNEOUS

AND

MIGMATITIL PARAGNEISS

ROCKS

PARAGNEISS

$\therefore y^{\prime} P^{\prime} \therefore-$

\begin{tabular}{|c|}
\hline$y \leq r-y$ \\
\hline$y s a$
\end{tabular}

Ysr

$y<h$

Ymg

yogr
MIODLE

PROTEROZOIC

\section{Y9g}

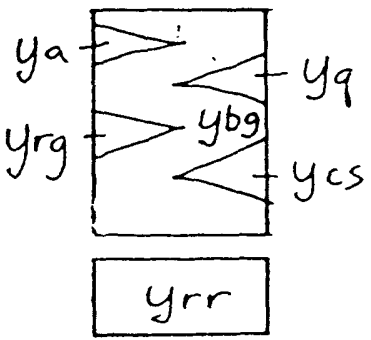

ybgr
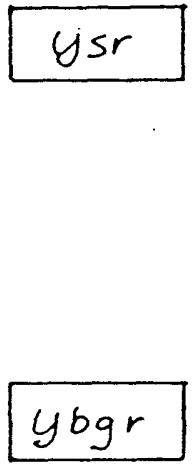

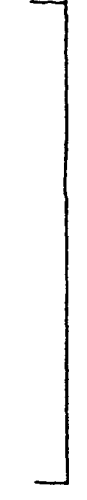

7

$y^{t} \leqslant y+a$ 
DESCRIPTION OF ROCK UNITS,

STRATTON MOUNTAIN QUADRANGLE

Hoosac Formation (Lower Cambrian-upper Proterozoic)

EZhcgt Lustrous green chlorite-chloritoid-garnet-muscovite (tparagonite)quartz schist

EZhd White dolomitic marble and pink calcitic dolomitic marble

EZhcb Coaley black, lustrous phyllite and albite-biotite-quartz schist

EZhg

Lustrous green, gray, large-garnet, muscovite-chlorite-quartz schist, locally containing chloritoid

EZhgab Light green to gray-green, albitic chlorite-muscovite-quartz schist, locally studded with garnet

EZhtm Dark-green to black, calcite-epidote-chlorite-actinolite greenstone, either massive or internally laminated, having thin cm-size laminae of silty graywacke and volcaniclastic rock

EZhrab Predominantly pale rusty-weathered muscovite-biotite-quartz schist, and dark gray albitic granofels; similar to EZhab but more micaceous and darker colored 
EZhab

EZhc

Light-gray, white albite-spotted, biotite-albite-quartz granofels

Yellowish to gray weathering pebbley feldspathic quartzite and metaconglomerate, with interlayers of biotite-muscovite quartz schist

Dalton Formation (Lower Cambrian and upper Proterozoic)

EZdbs

Dark gray to sooty-black carbonaceous phyllite and quartz-muscovitebiotite schist with minor interlayered feldspathic quartzite

$\in Z d$

Tan to rusty weathering flaggy feldspathic quartzite, white vitreous quartzite, and minor interlayered phyllite and muscovitic schist, well exposed on Stratton Mountain

$\in Z d q$

Tan weathering, massive to flaggy, gray vitreous quartzite; contains minor pebbley layers

EZdc

Orange to gray weathering quartz-pebble metaconglomerate with minor interlayers of biotite-muscovite-quartz schist

Basement rocks (Middle Proterozoic)

$Y_{p}$

Pegmatite-white to pinkish white biotite-granite pegmatite, garnetiferous pegmatite and less commonly white hornblende-diopsideplagioclase-rich pegmatite developed near calc-silicate rocks. Most abundant in rusty quartz-mica schist and gneiss (Yrg) and quartzite (Yq) and in migmatitic biotite granite gneiss (Ymg) 
Somerset Reservoir Granite (new name) ${ }^{\dagger}--$ light pinkish-gray, weathered, biotite-microcline-perthite porphyritic granite and pegmatitic granite. Contains large ovoidal to rectangular phenocrysts of microcline-perthite up to $4 \mathrm{~cm}$ in longest dimension that have rapikivi rims in less deformed rocks, but unit commonly is a highly deformed mylonite-augen.gneiss because of intense Paleozoic deformation in and near low angle thrust faults. Unit is traceable to type exposures on the hills east of Somerset Reservoir in the Mt. Snow quadrangle

Somerset Reservoir granite aplitic facies--white to pinkish white, medium-grained quartz oligoclase-microcline perthite leucogranite and pegmatitic granite transitional into and forming irregular border around Somerset Reservoir Granite (Ysr)

College Hill Granite Gneiss (new name) ${ }^{\dagger}--$ light-gray to medium-darkgray biotite-microcline-perthite granodioritic porphyritic gneiss and pegmatite. Unit is strongly deformed and lineated and saturated with less deformed irregular pegmatite segregations; passes gradationally into an envelope of migmatitic biotite-granite gneiss (Ymg)

t These new names will be proposed for adoption by the U.S. Geological Survey in a short article to appear in the U.S.G.S. Bulletin Stratigraphic Notes, 1988-89. 
Ymg

Ybgr

Migmatitic biotite granite gneiss--1ight gray to pinkish gray, medium-grained, massive to weakly foliated, magnetite-biotiteplagioclase-microcline granitic gneiss having indistinct layering and numerous pods and segregations of granite and micropegmatite; unit grades into Ych through development and enrichment in microcline perthite megacrysts. Interpreted as a migmatitic granite gneiss formed during intrusion of the College Hill Granite

Gray, biotite granite gneiss--light gray to white, medium-grained, massive to well-layered and migmatitic biotite-plagioclase-microcline granite gneiss. Commonly contains biotite and/or hornblende-rich $\mathrm{cm}^{-}$ scale mafic layers as well as larger traceable amphibolitic units (Ya). Considered to be intrusive into biotite gneiss (Ybg) and other layered gneisses and closely related to granitic unit Ymg and possibly units $\mathrm{Ych}$ and $\mathrm{Ygg}$

Ygg

Granite gneiss--pink, medium-grained, massive to weakly foliated biotite-microcline plagioclase-quartz gneiss; generally more felsic than other granitic gneiss units. Traceable into Woodford quadrangle where it underlies Glastenbury Mountain; considered to be intrusive into layered gneiss units (Ybg, Yq, etc.) and possibly correlative with granitic units Ybgr, Ymg, and Ych

Ybg Biotite-quartz-plagioclase gneiss--medium-dark-gray, wel1-layered biotite-quartz-plagioclase gneiss, commonly containing more mafic hornblende-biotite-rich layers as well as thin amphibolites and rusty-weathering quartz-mica schist 
Yrg

Yq

Ycs

Ya

Rusty weathering quartz schist and gneiss--dark tan to rusty tan weathering, muscovite-biotite-quartz-plagioclase gneiss, locally having discontinuous ribs of dull-gray, deeply pitted garnetiferous quartzite 1-4 cm thick, and beds of biotite-muscovite-garnet-quartzplagioclase gneiss up to $8 \mathrm{~m}$ thick. Unit is commonly extensively retrograded to muscovite-chlorite-quartztchloritoid phyllite that contains heavily chloritized relicts of garnet and red-brown biotite, and abundant pods of coarse pegmatite as on east side of Stratton Mountain

Quartzite--light bluish gray, vitreous, commonly pitted garnetiferous quartzite in layers up to $5 \mathrm{~m}$ thick, and more rusty weathered, tan to yellowish gray, muscovite-biotite-magnetite-garnet-bearing quartzite

Calc-silicate gneiss--consists of one or more of the following rock types: dark-green to black, coarse-grained, hornblende-diopside rock, grass-green diopside-quartz gneiss or granofels, or welllayered hornblende-diopside and plagioclase-microcline-epidote-quartz gneiss; all varieties interlayered with rusty to dark gray weathered sulfidic biotite schist or gneiss

Amphibolite--dark-green to black, massive to well-foliated, finegrained biotite-hornblende-plagioclase amphibolite, locally with pods of coarse-grained garnet-hornblende-diopside ampibolite as much as $0.5 \mathrm{~m}$ in thickness which have rusty-weathering sulfide-rich zones 
Rusty-ribbed gneiss--rusty weathering quartz-plagioclase-biotitemuscovite gneiss and schist with thin quartz-rich laminae and rusty micaceous interlayers, plus thicker, blue vitreous quartzite beds. Locally contains garnet or diopside-green amphibole-sulfide-bearing layers

Trondjhemite gneiss--light gray to white, chalky-white weathering, massive to weakly foliated biotite-spotted, biotite-microclinequartz-plagioclase gneiss or coarse-grained granofels having indistinct layering or more conspicuous hornblende-biotite-bearing dioritic layers as much as $1 \mathrm{~m}$ thick. Locally distinct pinstripe foliation and extensive alteration of plagioclase to albite-epidote and sericite due to later deformation and retrograde metamorphism. Interpreted as a metatrondhjemite and metadacite Dark-green to black, massive to faintly foliated, fine-grained hornblende-plagioclase amphibolite. Occurs as 1-5 m thick layers in metat rondhjemite $(Y t)$ 
EXPLANATION OF SYMBOLS,

STRATTON MOUNTAIN QUADRANGLE

Contact -- solid where accurately located, dashed approximate, dotted under water

Planar and linear features, may be combined

Thrust fault -- teeth on upper plate; solid where accurately located, dashed approximate, dotted under water

Vein quartz in brittle fractures

Strike and dip of bedding -- where shown, ball indicates facing direction known from sedimentary structures

inclined

35

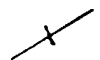

vertical

$\alpha / 78$

overturned

Strike and dip of compositional layering or gneissosity of probable Middle Proterozoic age

inclined 


\section{vertical}

Strike and dip of gneissosity or coarse foliation of probable

Middle Proterozoic age in Middle Proterozoic granitic rocks

$$
\text { inclined }
$$

vertical

Strike and dip of foliation or schistosity of Paleozoic age formed in early generations of Taconian(?) deformation in cover sequence rocks, or foliation of uncertain age in Middle Proterozoic rocks

inclined

vertical

Strike and dip of foliation or schistosity of Paleozoic age and parallel bedding composite fabric formed in early generation of Paleozoic deformation (Taconian)

inclined

vertical 
Strike and dip of mylonitic foliation spatially associated with Taconian(?) thrust faults or ductile deformation zones (Paleozoic $\mathrm{F}_{2}$ structures); arrow, where present, shows bearing and plunge of associated prominent mullion structure, smear lineation, or quartz rodding
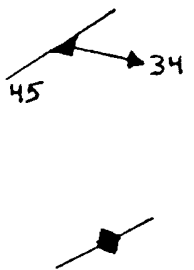

230
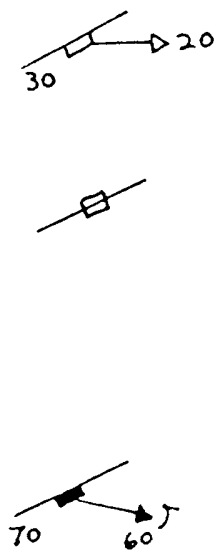

inclined

vertical

Approximate strike and dip of highly crenulated gneissosity in Proterozoic rocks or of schistosity in younger rocks; folding Paleozoic

Strike and dip of axial surface of fold in Middle Proterozoic rocks of probable Middle Proterozoic age (or of early generation Paleozoic fold in cover sequence rocks); arrow when present shows direction and amount of plunge of fold axis

$$
\begin{aligned}
& \text { inclined } \\
& \text { vertical }
\end{aligned}
$$


Strike and dip of axial plane of late-generation crenulationcleavage fold (or associated late slip cleavage) (Paleozoic (Acadian?) $\mathrm{F}_{3}$ or $\mathrm{F}_{4}$ structure), arrow when present shows direction and amount of plunge of fold axis

inclined

vertical

Bearing and plunge of axis of minor Middle Proterozoic fold in Middle Proterozoic rocks expressed by orientation of high-grade minerals, or minor early-generation Paleozoic fold in cover sequence rocks, or of lineation caused by intersection of Middle Proterozoic foliation with Paleozoic mylonitic foliation

Location of sample used for ${ }^{40} \mathrm{Ar} /{ }^{39} \mathrm{Ar}$ dating of hornblende, ( yielding a discordant release spectrum and approximate age of $850 \mathrm{Ma}^{\dagger}$

† Sample Wl178 in Ratcliffe, N.M., Burton, W.C., Sutter, J.F., and Mukasa, S.B., l988, Stratigraphy, structural geology, and thermochronology of the northern Berkshire massif and southern Green Mountains, in Bothner, W. A., ed., Guidebook for field trips in southwestern New Hampshire, south-eastern Vermont, and northcentral Massachusetts: New England Intercollegiate Geological Conference, 80 th Annual Meeting, p. 1-23, 126-135. 